\title{
Nanoparticle of Silver Nitrate (Ag2NO3) and Carbamate (CO2NH3 derivatives) For Vector Control of Aedes aegypti
}

\author{
Mursid Raharjo ${ }^{1, *}$, Agus Subagyo ${ }^{2}$, and Sulistyani ${ }^{3}$ \\ ${ }^{1}$ Magister of Evironmental Health, Faculty of Public Health, Diponegoro University, Semarang - Indonesia \\ ${ }^{2}$ Faculty of Sains and Mathematics, Diponegoro University, Semarang - Indonesia \\ ${ }^{3}$ Magister of Evironmental Health, Faculty of Public Health, Diponegoro University, Semarang - Indonesia
}

\begin{abstract}
The climate change has an impact on various lives, including in the vector breeding. The Aedes aegypti resistance as an infectious agent of dengue fever is harmful for life, especially to non-target organisms and the environment. Nano-silver (Ag2NO3), is a new form of engineering in vector control. The aim of this research was the toxicity test of nano-silver (Ag2NO3) and carbamate (CO2NH3 derivatives) on Aedes aegypti larvae. This was a laboratory research (true experiment), used for 3-4 instar stage larvae toxicity test. The number of samples was calculated using an experimental approach, with a completely randomized design. As simply, can formulated as follows, (t-1) (r-1)>15. The amount of this samples were 14. The toxicity test with carbamate compounds, at concentration $0.01 \mathrm{mg} / 1$ as many as $80 \%$ larvae were death, whereas on concentrations $0.5 \mathrm{mg} / 1$ as many as $92 \%$ of the test animals were death. Toxicity test with nano-silver on concentration $0.3 \mathrm{mg} / 1$, all of the test animals $(100 \%)$ experienced were death. The results of the observations also showed that the instar more active in the low cocentration of Ag2NO3 (0.01 $\mathrm{mg} / 1-0.1 \mathrm{mg} / \mathrm{l})$. The conclusion are, nano-silver is more effective than carbamate compounds, and there is a potential for resistance.
\end{abstract}

Keywords : Nanosilver; Carbamate; Aedes aegypti.

\section{Background}

The climate change has an impact to various lives including the vector breeding [1]. The changes effecting to vectors especially in bionocyclic vectors, including Aedes aegypti as vector of infectious dengue fever [2]. Climate change also has the potential to caused the appearance of rare species [3].

The occurrence of Aedes aegypti resistence as a carrier of dengue fever is dangerous for life [4]. Resistance demanding the dose increase of insecticide use. The dose increase threaten the non target organism and harmful for the vector's environment [5].

Carbamate $\left(\mathrm{CO}_{2} \mathrm{NH}_{3}\right.$ derivat $)$ commonly use for vector control [6]. The result of another research show that $100 \%$ resistace on $0,03 \mathrm{mg} / 1$ concentration [7]. WHO classified the active materials of carbamate types carbofuran, butocarboxim dan butoxycarboxim to class Ib (Highly hazardous) [8].

Nanotechnology with its growth has been expanding to some utilization [9]. In the health sector, there was some materials tried in another country with Nano- $\mathrm{TiO}_{2}$, Sillica and herbs material [10]. Nanosilver which come from $\mathrm{Ag}_{2} \mathrm{NO}_{3}$ easy to obtain and can be used in the health sector. The biomecanism principle of carbamate and organofosfat which inhibit Acethylcholinesterase (AChe), expected has a change when synthesized with nano-silver. The nano-silver particles, beside on theory able to penetrate Ache enzyme, so it more effective and could use in lower dose [4].

The problem on this research is how to diversify of $\mathrm{Ag}_{2} \mathrm{NO}_{3}$ nanoperticles for vector control compared to carbamate compounds. The aim of this research is to do toxicity test of nanoparticles $\left(\mathrm{Ag}_{2} \mathrm{NO}_{3}\right)$ and carbamate $\left(\mathrm{CO}_{2} \mathrm{NH}_{3}\right.$ derivat $)$ to the Aedes aegypti larvae

\section{Methods}

This was laboratory research (true experiment) by controlling all of variables. The research started with nano-silver making which come from $\mathrm{Ag}_{2} \mathrm{NO}_{3} . \mathrm{Ag}_{2} \mathrm{NO}_{3}$ materials obtained from chemical supplier. Carbamate obtained from the markets product and standarized to determine the concentration. The Aedes aegypti vector which used for toxicity test was larvae instar 3-4. Toxicity test for larvae used the liquid-immersion method. Amont of the samples measured by experimental approach with complete randomized design. As simply, can be formulated as $(\mathrm{t}-1)(\mathrm{r}-1)>15$. [11-12]. The amount of the samples was 14 . The solutions used as test solutions were carbamate (Furadan 3gr) and $\mathrm{Ag}_{2} \mathrm{No}_{3}$ nano-particle $(0.2 \%)$. Steps of making the mother liquor (Furadan 3gr) to obtain two concentrations are $0,1 \mathrm{ppm}$ and $1 \mathrm{ppm}$. The

\footnotetext{
* Corresponding author: arsikazk@gmail.com
} 
$\mathrm{Ag}_{2} \mathrm{NO}_{3}$ nano-particle solution designed with $2 \mathrm{ppm}$ concentration of mother liquor.

Toxicity test use the Aedes aegipty species instar 3-4 with carbamate and $\mathrm{Ag}_{2} \mathrm{NO}_{3}$ solutions. The steps of this test are 1) Transparant glasses are prepared about 14 pieces used for 2 types of solutions test with 6 concentrations and 1 control in each solution. 2) Observations were did in the first 2 hours then the observations were recorded. 3) Observations carried out again in the next 24 hours then recorded the results of these observations.

\section{Results}

\subsection{Carbamate (CO2NH3 derivatives)}

Carbamate toxicity test was carried out on 25 instars of Aedes aegypti, using controls. Observations are made in the first 2 hours and after 24 hours. In the first 2 hours, at concentration $0.01 \mathrm{mg} / 1$ as many as $56 \%$ larvae of Aedes aegypti was died. At the highest concentration at the test $0.5 \mathrm{mg} / 1,84 \%$ of the larvaes were died. There was percentage increase from $56 \%(0.01 \mathrm{mg} / \mathrm{lt})$ to $84 \%(0.5$ $\mathrm{mg} / \mathrm{lt}$ ).

After 24 hours observation of the larvae test, it was obtained as follows, at concentration $0,01 \mathrm{mg} / 1,80 \%$ of the test animals experienced were death. The death increased by $92 \%$ at concentration $0,5 \mathrm{mg} / \mathrm{lt}$. The results of the carbamate toxicity test on instar 3-4 of Aedes aegypti are presented in Table 1 and Figure 1.

\subsection{Ag2NO3 Nanoparticles (Silver Nitrate) Test}

Nano Silver nitrate particles $\left(\mathrm{Ag}_{2} \mathrm{NO}_{3}\right)$ toxicity test were carried out on Aedes aegypti larvae instar 3-4. The total of 25 larvae were tested with various nano concentrations of silver nitrate particles. The observations are obtained as follows, in the first 2 hours observation, at $0.01 \mathrm{mg} / 1$, no test animals were died. Likewise the $0.05 \mathrm{mg} / \mathrm{l}$ and 0.1 $\mathrm{mg} / \mathrm{lt}$. The $0.3 \mathrm{mg} / \mathrm{l}$ concentration, there were $4 \%$ of animal's death, while in $0.4 \mathrm{mg} / 1$ and $0.5 \mathrm{mg} / 1$ concentration, all test animals (100\%) experienced were death. At $0.01 \mathrm{mg} / 1,0.05 \mathrm{mg} / \mathrm{l}$ and $0.1 \mathrm{mg} / 1$ concentration shows the test animals move more actively.

At 24 hours observation, obtained at concentrations $0 ., 01 \mathrm{mg} / 1$ there were no $(0 \%)$ test animals were death. The new death of test animals were seen at concentrations of $0.05 \mathrm{mg} / 1(4 \%)$ and $0.1 \mathrm{mg} / 1(4 \%)$. At concentrations $0.3 \mathrm{mg} / 1$ to $0.5 \mathrm{mg} / 1$ all of test animals (100\%) experienced were death. The results of the observations also still show the occurrence of instar activity in the low concentration of $\mathrm{Ag}_{2} \mathrm{NO}_{3}$ which is $0.01 \mathrm{mg} / 1-0.1 \mathrm{mg} / 1$. The results of the toxicity test of $\mathrm{Ag}_{2} \mathrm{NO}_{3}$ nanoparticles on instar 3-4 of Aedes aegypti are presented in Table 1 and Figure 2.

Table 1. The result of $\mathrm{Ag}_{2} \mathrm{NO}_{3}$ and carbamate toxicity test on instar 3-4 Aedes aegypti

\begin{tabular}{|c|c|c|c|c|c|}
\hline $\begin{array}{l}\text { Concentration of } \\
\text { Karbamat (mg/l) }\end{array}$ & 2 hours & 24 hours & $\begin{array}{c}\text { Concentration } \\
\text { of } \mathrm{Ag}_{2} \mathrm{NO}_{3} \\
(\mathrm{mg} / \mathrm{l})\end{array}$ & 2 hours & 24 hours \\
\hline 0,01 & $56 \%$ & $80 \%$ & 0,01 & $0 \%$ & $0 \%$ \\
\hline 0,05 & $68 \%$ & $80 \%$ & 0,05 & $0 \%$ & $4 \%$ \\
\hline 0,1 & $76 \%$ & $88 \%$ & 0,1 & $0 \%$ & $4 \%$ \\
\hline 0,3 & $84 \%$ & $88 \%$ & 0,3 & $4 \%$ & $100 \%$ \\
\hline 0,4 & $84 \%$ & $92 \%$ & 0,4 & $100 \%$ & $100 \%$ \\
\hline 0,5 & $84 \%$ & $92 \%$ & 0,5 & $100 \%$ & $100 \%$ \\
\hline
\end{tabular}




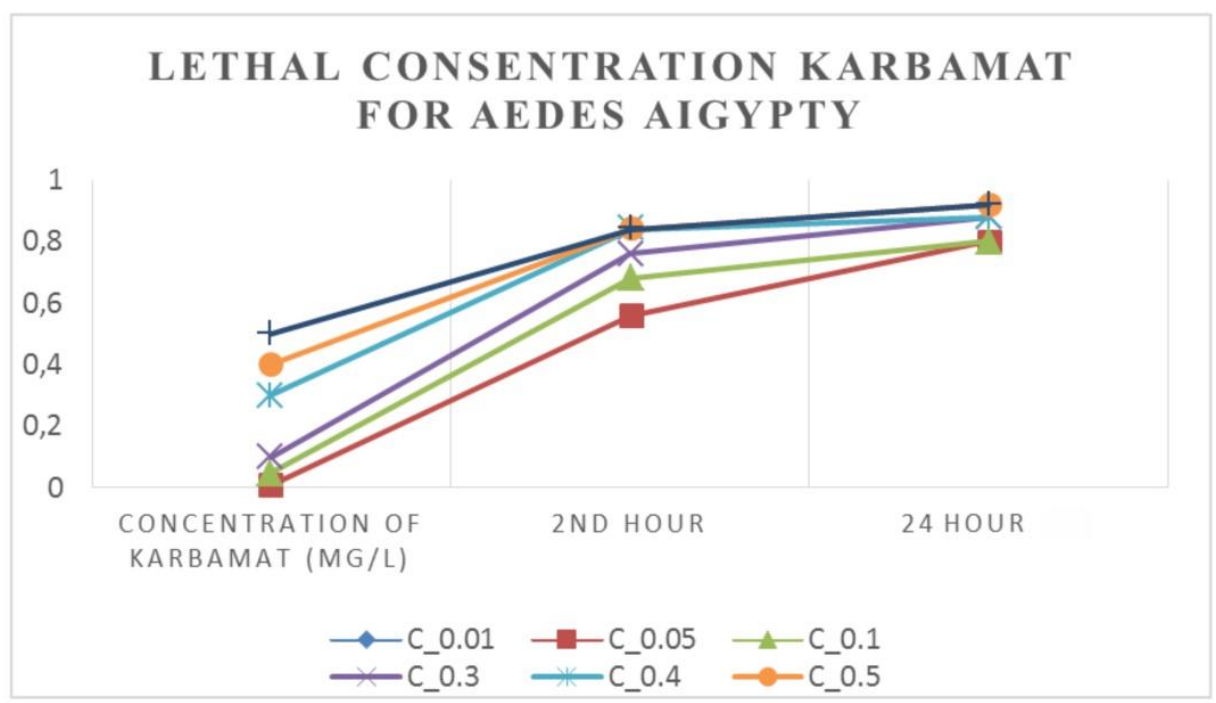

Fig. 1. The death percentage's development of instar 3-4 Aedes aegypti with carbamate (CO2NH3 derivatives)

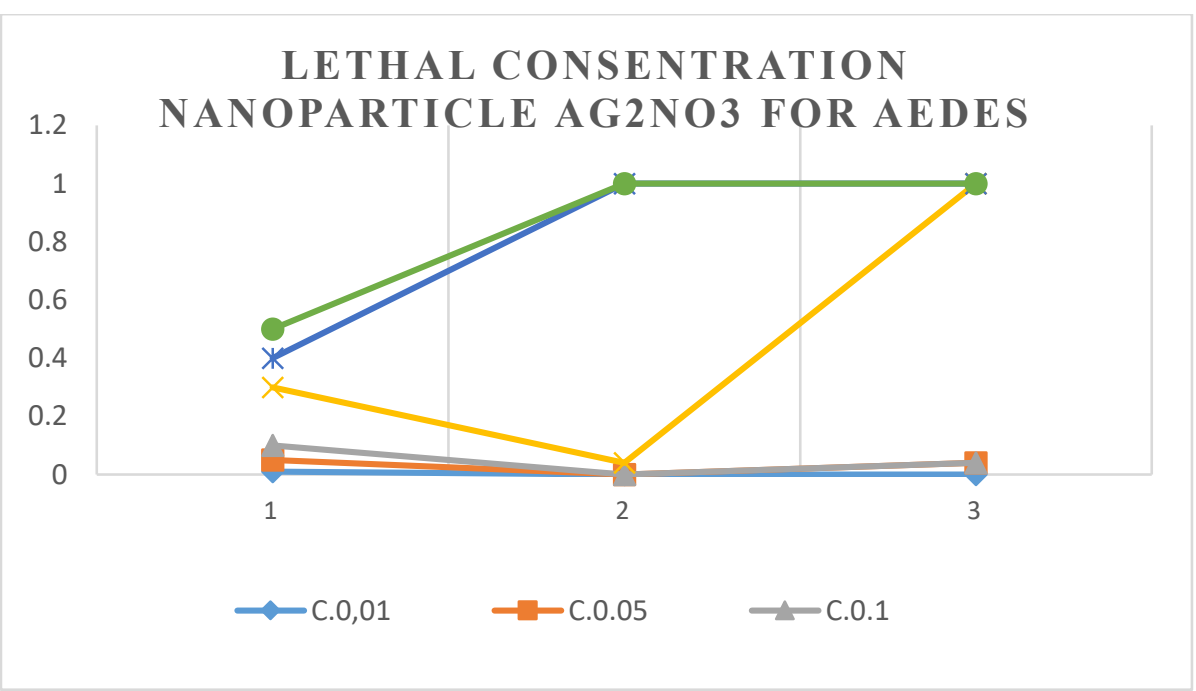

Fig. 2. The death percentage's development of instar 3-4 Aedes aegypti with nano materials of $\mathrm{Ag}_{2} \mathrm{NO}_{3}$

\section{Disscusion}

Chemical control by utilizing various synthetic material, processed, along with organophosphate and carbamate derivatives are still widely used. Control is carried out to the vector at the larvae-pupa stage until the mature stage. Oxygen and mineral that contains in the water are utilized by Instar stage of Aedes aegypti to live in the water. Oxygen absorption through the surface of the skin and minerals by mouth are the biochemical mechanism in the life cycle of larvae. Biochemical mechanisms of larvae's body are used to choose the type of intervention so that the larvae are easily destroyed and not given the chance to become a mosquito.

The results of the study of silver nanoparticle toxicity tests (Ag2NO3) shows, that at low concentrations $(0,01-$ $0,1 \mathrm{mg} / \mathrm{lt}$ ) the higher activity of Aedes aegypti larvae occurs. This high activity shows the suitability of nitrate minerals as essential material for growth and development to boost larvae activity.
Acetylcholinesterase Enzym (AChE) can grow optimally. According to Liebig's theory that the growth of organisms is controlled by a limiting factor [5].

At a concentration of $0.3 \mathrm{mg} / \mathrm{lt}$, all test animals $(100 \%)$ were died. This concentration is smaller than carbamate. At the same concentration, carbamate can only kill $88 \%$ of test animals. Heeding to the characteristics of nanoparticles, it has size $1-100 \mathrm{~nm}$, and has a high penetrating power to media around it.

At low concentration, the mortality rate of toxicity test with carbamate was higher than nano particle because of the active materials of carbamates is poisonous although in the low concentration, while the nitrate is not poisonous in the low concentration and can be the essential material for larva's growth. In the high concentration, the nitrate can be poisonous for the organism life, so thats why it can kill all of animal test and be more effective with its smaller size than carbamate, so it easily inhibit the larvae enzym. Nano-silver $\left(\mathrm{AG}_{2} \mathrm{NO}_{3}\right)$ material has smaller particle size than larvae's pores in the inter-abdominal segment. Silver nitrate compounds will react directly with the ACHe hormone system, so that it will directly affect the larvae's 
metabolism. The inhibition of the enzyme's performance causes the death of larvae. Carbamate compounds with a larger diameter only possible to enter the larvae through the digestive tract which caused only a part of the compound reacts with Ache enzym (Acethyl Cholinesterase), so it can be understood why Nano-silver concentrations are lower than Carbamat $\left(\mathrm{CO}_{2} \mathrm{NH}_{3}\right.$ derivatives) concentration.

The larvae breathe through the funnel on their tail, and enter the food through the gastrointestinal tract and through the abdominal pores [13]. Larval body pores are estimated to have a larger size than $\mathrm{Ag}_{2} \mathrm{NO}_{3}$ nano particles. Overall, nano refers to a size scale between 1 nanometer $(\mathrm{nm})$ and $100 \mathrm{~nm}$. In comparison, the wavelength of visible light is between $400 \mathrm{~nm}$ and 700 $\mathrm{nm}$. A leukocyte has a size of $10,000 \mathrm{~nm}$, a bacterium $1000-10000 \mathrm{~nm}$, a virus $75-100 \mathrm{~nm}$, a protein of 5-50 nm, deoxyribonucleic acid (DNA) $\sim 2 \mathrm{~nm}$ (width), and atoms of $\sim 0.1 \mathrm{~nm}$. In this scale, the physical, biological and chemical characteristics of materials have fundamentally difference between one and another and often unexpected actions are showed from them [14].

$\mathrm{Ag}_{2} \mathrm{NO}_{3}$ nanoparticles are $1-100 \mathrm{~nm}$ in size. These particles have penetrating power on Aedes larvae. Nanoparticles are dispersions of particles or solid colloid structures that the diameter is start from 1 to $1000 \mathrm{~nm}$. They consist of synthetic, semi-synthetic and natural polymer active therapeutic molecules that have the ability to be trapped, encapsulated, dissolved, absorbed, or chemically attached [15]. Due to biodegradability, biocompatibility, and flexibility in utilization $[16,17]$.

The potential for the entry of nanoparticles through pores and food tract, causes increasing of particles's rate to interact with the enzyme system in the body of the larvae. So that in low concentrations, it has accumulated in the body of the larvae which is able to inhibit the work system of the Acetylcholinesterase Enzym (AChE). It is understand that the reason why Nano Silver concentration $\left(\mathrm{Ag}_{2} \mathrm{NO}_{3}\right)$ is lower than carbamate.

This study strengthens the present study. There is a better expediency, especially nano particles $\mathrm{Ag}_{2} \mathrm{NO}_{3}$ against other organisms. Compared to the use of other insecticides, $\mathrm{Ag}_{2} \mathrm{NO}_{3}$ Nano is more environmentally friendly. Artificial nanoparticle particles have been known to affect non-target aquatic organisms [18]. There is information about the occurrence of acute toxicity to non-target aquatic species. Silver that are synthesized by Plumeria rubra- and Pergularia daemia nanoparticles did not show toxicity effects on P. reticulata fish after 48 hours of exposure to $\mathrm{LC}_{50}$ [19]. Silver nanoparticles were synthesized using extracts of Solanum nigrum berry which were non-toxic to two mosquito predators, Toxorhynchites larvae and Diplonychus annulatum [20]. Nano Silver can be applied to various health care products [10]. The most interesting thing is the potential use of silver nanoparticles (AgNP) in mosquito control. More than several groups have reported AgNP synthesizing which can limit the growth of larvae and/or pupae from Andopheles [21-22].

Carbamat (CO2NH3 derivatives)

Carbamate is the most widely used compound for insecticides. Pesticides that are categorized as carbamates: propoxur, furadan and bendiocarb [6, 23]. Insecticides made from active carbamate (methonyl) in Ae. aegypti, the concentration needed for LC50 is 0.802 $\mathrm{mg} / 1$ and LC95 is $18.832 \mathrm{mg} / 1$. Effective concentration of Ae. aegypti requires a smaller amount than carbamate, for LC50 is equal to $0.64 \mathrm{mg} \mathrm{/} 1$ [7].

The results of the study for carbamate toxicity showed that concentration of $0.5 \mathrm{mg} / \mathrm{lt}$, the mortality rate was $92 \%$. At a lower concentration of $0.01 \mathrm{mg} / \mathrm{lt}$, the mortality of test animals was $80 \%$. A concentration greater than $0.5 \mathrm{mg} / \mathrm{lt}$ is needed to kill all test animals. These concentration figures resistance of Aedes aegypti larvae.

This research also occurs in other countries. Variations in mortality and Aedes's resistance to insecticides in various countries were influenced by the different bio-ecological characteristics of each mosquito. These characters are controlled by the metabolism intensity of Monooxygenases enzym, Esters enzym, Acetylcholinesterase enzym (AChE) and Glutathione-Stransferase (GST) enzymes in the process of detoxifying insecticides [4].

That performance of the enzyme as a determinant of insecticide absorption against the target mosquito. The specific target site is usually an enzyme or protein that acts as an effector of insecticides [10]. Other studies show the high metabolic activity of enzymes Esters in Aedes aegypti, In Sri Lanka it causes Potential Resistence of Malathion Low activity of the enzyme Glutathione-Stransferase (GSTs) in Aedes aegypti and also it causes mosquito has a high susceptibility status to $\lambda$ Cyhalothrin [24-26].

Carbamates act to inhibit the acetylcholinesterase enzyme (AChE) which caused the accumulation of acetylcholine $(\mathrm{ACh})$ Acetylcholine which accumulated in the Central Nervous System (CNS) will induce tremors, incoordination, convulsions and others [7]. Acetylcholinesterase (AChE) is a proven target for controlling dengue mosquitoes (Aedes aegypti). A single amino acid mutation (G119S) in Aedes aegypti forms AChE-1 (AgAChE), which provides resistance to AChE inhibitors. G119S resistance, AgAChE mutants, and high toxicity to $A n$. gambiae has the effect of properties changes. Inhibitors can be raised from 'core' shape of carbamates like aldicarb and pirazol-4-yl methylcarbamat $4 \mathrm{a}$ - e although none of these compounds show selectivity which is useful for inhibiting AgAChE to AChE [6].

The high concentration of carbamate to kill Aedes aegypti larvae, caused by the entry of that material through only the gastrointestinal tract. High concentration is needed to achieve the occurrence of enzyme system disorders in Aedes aegepty larvae. Acetylcholinesterase Enzym (AChE), as a controlling metabolism of Aedes aegepty larvae, has not been completed with $0.5 \mathrm{mg} / 1$ concentration of carbamate.

The synthesis of nano-silver particles $\left(\mathrm{Ag}_{2} \mathrm{NO}_{3}\right)$ with carbamate is the next step to find the effective concentration in the use of carbamate, or nano silver independently. Synthesis is possible for the combination of chemical entry systems into the larva's body. The nanosilver able to penetrate through by the pores between segments in the abdomen, while carbamates can enter the 
body of the larvae through the gastrointestinal system. Synthesis also can produce the new compounds with specific properties of $\mathrm{Ag}_{2} \mathrm{NO}_{3}$ and $\mathrm{CO}_{2} \mathrm{NH}_{3}$, so it is possible will be a substitution reaction wich resulting a new compound of $\mathrm{Ag}_{2} \mathrm{NH}_{3}$, with the cutting of $\mathrm{NH} 3$ chain from $\mathrm{CO} 2 \mathrm{NH} 3$.

\section{Conclusion}

The concentration of $0.5 \mathrm{mg} / \mathrm{lt}$ carbamate compounds $\left(\mathrm{CO}_{2} \mathrm{NH}_{3}\right)$ can kill $92 \%$ of test animals while the concentration of $0.3 \mathrm{mg} / \mathrm{l}$ nano-sliver $\left(\mathrm{Ag}_{2} \mathrm{NO}_{3}\right)$ can kill $100 \%$ of them. The result shows that nanosilver $\left(\mathrm{Ag}_{2} \mathrm{NO}_{3}\right)$ is more effective to kill animals test (Aedes aegypti larvae)

\section{References}

1. M. Rahardjo, IJSBAR 22, 1 (2015)

2. M. Rahardjo, Y.H. Darundiati, Praba G., Proceding of International Meeting Of Public Health (IMOPH), Kne Publisher, (2018)

3. M. Rahardjo, Y.H. Darundiati, Praba G., IJPHRD 9, (2018)

4. Dono D, et al, J. Entomol. Indon. 7, 1, 9-27, (2010)

5. Beroya AM, Mengenal Lingkungan Hidup (Yakoma, 2000)

6. Wong MD et al, Plos One 7, 10, (2012)

7. Pujiastuti E, Aspirator 2, 2, 77 -83, (2010)

8. World Health Organization (WHO). The WHO Recommended Classification of Pesticides by Hazard and Guidelines to Classification, (2009)

9. Subagyo A, IOP Conf. Series: Journal of Physics, (2018)

10. Amerasan D, et al, J Pest Sci, 89, 249-256, (2016)

11. Haldar KM, et,al , Parasitol Res, doi: 10.1007 / s00436-013-3288-4, (2013).

12. Santhoshkumar T, et al, Parasitol Res, 108, 693702, (2013)

13. Sutiningsih D, Martono E, Satoto TBT, AJPJR, 11, 10, (2018)

14. Pam DD et al, IJHAS, 16, 2, (2017)

15. IOPScience, Nanotechnology encompasses the Understanding of Fundamental physic, Chemistry, 15, (2019)

16. Denis et al, Ther, 3, 4, (2015)

17. Sailaja AP, Int J Pharm, 3, 45-50, (2016)

18. Benelli G, JKSUS, 424-435, (2017)

19. Salunkhe RB, Parasitol Jounal, 109, 823-831, (2015)

20. Santhoshkumar T et al, Parasitol Res, 108, 693702, (2011)

21. Birla S, Lett Appl Microbiol 48,173-179, (2016)

22. Murugan K, Parasitology Journal, 153, 129138, (2015)

23. Kenneth D, Organophosphate Toxicity, eMedicie, Drug and Deseasis, (2018)

24. N. Endo, E.A.B. Eltahir, Malaria Journal, 48, (2018)
25. Nwane P, Etang J, Chouaïbou M, Toto JC, Koffi A, Mimpfoundi R, et al. Parasit Vectors, 6, 41, (2013)

26. Oduola AO, Idowu ET, Oyebola MK, Adeogun AO, Olojede JB, Otubanjo OA, et al. Parasit vectors, 11, 5, 116, (2012) 